\title{
Effect of Weather Parameters on the Development of Post Harvest Rots of Papaya
}

\author{
Priyanka Bhardwaj, Kumud Jarial*, R. S. Jarial and Dinesh Kumar \\ Department of Plant Pathology, College of Horticulture and Forestry, \\ Neri, Hamirpur (HP) -177001 India \\ *Corresponding author
}

\begin{abstract}
A B S T R A C T
Postharvest rots of papaya reduce quality as well as quantity of papaya (Carica papaya L.). Due to firm texture, various microorganisms attack the fruit during ripening stages and cause losses. During the present investigation, effect of various weather factors on the progress of different rots was studied during the year 2019-20. However, storage conditions could not be recorded but, data in terms of normal weather conditions such as monthly average minimum temperature, average maximum temperature and average relative humidity of district Hamirpur were recorded and correlated with disease abundance of different rots viz., anthracnose (Colletotrichum fructicola and C. truncatum), Rhizopus stolonifer, Aspergillus flavus, Fusarium pallidoroseum and Alternaria sp. under study during different months to calculate simple as well as partial correlation coefficients and multiple regression equation. Weather parameters like temperature and relative humidity were found to influence the abundance of these rots to a significant level. Rhizopus rot was positively and significantly correlated with average minimum temperature, Aspergillus rot was positively and significantly correlated while, Fusarium rot was negatively and significantly correlated with average maximum as well as average minimum temperature. Regression equation with weather parameters revealed that these factors could influence the outbreak of rots up to $69.50,13.00,45.40,55.70,59.20$ and 62.30 per cent in case of $C$. fructicola, C. truncatum, R. stolonifer, A. flavus, F. pallidoroseum and Alternaria sp., respectively.
\end{abstract}

\section{Introduction}

Papaya (Carica papaya L.) also called common man's fruit, is a native of tropical America (Singh, 1990) and is grown throughout the tropics and subtropics for its melon like fruit and ranks third in importance among fruits (Alvarez and Nishijima, 1987).
The leading global producers of papaya are Brazil, Colombia, Democratic Republic of Congo, Ethiopia, Guatemala, India, Indonesia, Mexico, Nigeria and Phillippines (Lustria et al., 2009). Papaya fruits are highly susceptible to diseases caused by microorganisms mainly fungi, as papaya fruits contain high moisture and nutrients (Sankat and Maharaj, 1997). 
Post-harvest losses due to fungal infections are significantly more in papaya fruits. The susceptibility of papaya fruit to several diseases is a major reason for extensive postharvest losses during handling and storage (Zhu et al., 2013). Storage conditions of papaya like temperature and relative humidity play an important role in the development of different post harvest rots in papaya. Maximum fungal rot in papaya, caused by fungi such as Rhizopus sp. Aspergillus sp., Fusarium sp., and Colletotrichum sp. occurs between at a temperature range of $30-35^{\circ} \mathrm{C}$ and relative humidity (RH) between 60-80 per cent (Baiyewu and Amusa, 2005). According to Pooja et al., (2012) optimum temperature for post harvest rots in papaya ranges between $17-30^{\circ} \mathrm{C}$ with $\mathrm{RH}$ of 80 per cent. Keeping in view the importance of post harvest rots of papaya, present studies were conducted with an objective to find correlation of temperature and relative humidity with the abundance of the post harvest rots associated with papaya fruits.

\section{Materials and Methods}

A routine survey and surveillance was conducted during the year starting from May, 2019 to April, 2020 in the local fruit markets i.e. Hamirpur, Nadaun, Sujanpur, Sulagwan and Barsar of district Hamirpur (Himachal Pradesh) to record the abundance (\%) of different post harvest rots of papaya. From each market, 15 diseased fruits were collected and brought to laboratory for identification of a particular rot and pathogen associated with it. The rot was identified on the bases of symptoms produced and associated pathogen was identified on the bases of microscopic and cultural characters. Disease abundance of each rot was then calculated as per the following formulae:

\section{Disease abundance $(\%)=\frac{\text { Number of fruits affected by a particular rot }}{\text { Total number of diseased fruits }} \times 100$}

Final identification of these pathogens was confirmed from ITCC, New Delhi National Centre of Fungal Taxonomy. However, one pathogen associated with the rot exhibiting very low abundance was identified on the basis of its microscopic characters up to genus level only. Simultaneously, data in terms of average minimum temperature, average maximum temperature and average relative humidity pertaining to district Hamirpur were recorded daily from website https://www.accuweather.com w.e.f. May, 2019 to April, 2020 and averaged for each month, in order to correlate the disease abundance of each rot with these weather parameters. Simple and partial correlation coefficients between abundance of different rots and three weather parameters under study were calculated and multiple regression equations were devised by taking disease abundance of individual rot as dependent variable and all three weather parameters as independent variables.

\section{Results and Discussion}

\section{Identification of different post harvest rots and symptomatology}

Six fungal species viz., Rhizopus stolonifer, Aspergillus flavus, Fusarium pallidoroseum (identified from ITCC, New Delhi under Accession No. 11309.20, 11310.20 and 11308.20, respectively), Colletotrichum fructicola, C. truncatum (identified from National Centre of Fungal Taxonomy as under Id No. 9013.20 and 9014.20, respectively) and Alternaria sp. (identified in the laboratory itself on the basis of mycelial and spore characters) were found to be 
associated with different types of post harvest rots in papaya. Symptoms of anthracnose caused by $C$. fructicola were recorded as dark brown to black coloured sunken water soaked spots with orange coloured acervuli in the form of concentric rings (Figure 1), while that of $C$. truncatum were recorded as dark brown to black sunken lesions with black coloured acervuli in concentric rings (Figure 2). $R$. stolonifer produced a soft rot which developed white to grayish black fluffy mycelium bearing sporangia in the rotten portion (Figure 3). A. flavus produced soft rot bearing white mycelium with suppressed growth and green coloured conidial mass (Figure 4). In case of Fusarium rot, symptoms developed as sunken watery spots with white to yellowish or pinkish mycelial growth which later became soft with time (Figure 5) while, in case of Alternaria rot, symptoms were recorded as brown semi circular to circular spots covered with dark brown mycelium (Figure 6).

\section{Abundance of different post harvest rots in relation to weather parameters}

Averages of monthly weather parameters and abundance of various rots associated with papaya have been presented in Table 1 . It is clear from the table that average maximum temperature ranged from $18.19^{\circ} \mathrm{C}$ in January 2020 to $43.97^{\circ} \mathrm{C}$ in June 2019 , average minimum temperature ranged from $9.09^{\circ} \mathrm{C}$ in January, 2020 to $31.20^{\circ} \mathrm{C}$ in June, 2019 and average relative humidity ranged from 18.29 per cent in May, 2019 to 71.83 per cent in September, 2019. Individually, maximum abundance $(86.11 \%)$ of $C$. fructicola was recorded in the month July, 2019 when the average maximum temperature was $37.87^{\circ} \mathrm{C}$ and minimum temperature was $28.03^{\circ} \mathrm{C}$ with 55.29 per cent average $\mathrm{RH}$ and minimum abundance (11.00\%) was recorded in May, 2019, with significantly maximum temperature and minimum temperature of $41.26^{\circ} \mathrm{C}$ and $28.97^{\circ} \mathrm{C}$, respectively with 18.29 per cent average RH. Maximum abundance (83.31\%) of C. truncatum was recorded in the month September, 2019 with maximum average temperature of $33.90^{\circ} \mathrm{C}$ and minimum average temperature of $25.27^{\circ} \mathrm{C}$ with average 71.83 per cent $\mathrm{RH}$ while, minimum abundance $(66.10 \%)$ was recorded in December, 2019, when maximum and minimum average temperature was recorded to be $20.77^{\circ} \mathrm{C}$ and $11.71^{\circ} \mathrm{C}$, respectively with average RH of 50.75 per cent. As far as abundance of $R$. stolonifer was concerned, it was recorded to be maximum $(85.50 \%)$ in the month June, 2019 when maximum and minimum temperature were recorded to be 43.97 and $31.20^{\circ} \mathrm{C}$, respectively with average RH of 21.36 per cent. However, minimum abundance of $R$. stolonifer $(72.43 \%)$ was recorded in August, 2019 having maximum and minimum temperature of 35.13 and $26.74^{\circ} \mathrm{C}$, respectively with average $\mathrm{RH}$ of 68.60 per cent.

Maximum abundance (100\%) of A. flavus was recorded in the month July, 2019 when maximum temperature was $37.87^{\circ} \mathrm{C}$ while, minimum temperature was $28.03^{\circ} \mathrm{C}$ with average $\mathrm{RH}$ of 55.29 per cent. Minimum abundance of A. flavus (10.50\%) was recorded in May, 2019 when maximum and minimum temperatures were recorded to be 41.26 and $28.97^{\circ} \mathrm{C}$, respectively with average RH of 18.29 per cent. Maximum abundance $(86.44 \%)$ of $F$. pallidoroseum was recorded in the month March, 2020 with maximum temperature of $27.13^{\circ} \mathrm{C}$ and minimum temperature of $15.19^{\circ} \mathrm{C}$ with average $\mathrm{RH}$ of 58.40 per cent while, its minimum abundance (17.20\%) was recorded in July, 2019, when maximum and minimum temperatures were recorded to be 37.87 and $28.03^{\circ} \mathrm{C}$, respectively with an average $\mathrm{RH}$ of 55.29 per cent. Maximum abundance (12.06\%) of Alternaria sp. was recorded in the month of August, 2019 with average maximum 
temperature of $35.13^{\circ} \mathrm{C}$, average minimum temperature of $26.74^{\circ} \mathrm{C}$ and average $\mathrm{RH}$ of 68.60 per cent while, minimum mean abundance $(2.50 \%)$ was recorded in September, 2019, with average maximum and minimum temperature of 33.90 and $25.27^{\circ} \mathrm{C}$, respectively and average $\mathrm{RH}$ of 71.83 per cent.

\section{Simple correlation between different post harvest rots and weather parameters}

Simple correlation analysis between abundance of different rots and weather parameters has been presented in Table 2. It is clear from the table that anthracnose caused by $C$. fructicola was positively and nonsignificantly correlated with mean monthly maximum temperature (0.022), mean monthly minimum temperature (0.201) and mean relative humidity $(0.526)$ while, that caused by $C$. truncatum was negatively and nonsignificantly correlated with mean monthly maximum as well as minimum temperature (3.555 and -0.340 , respectively) and positively and non-significantly correlated with mean RH (0.250).

The simple correlation analysis between abundance of rot caused by $R$. stolonifer and weather factors revealed its positive and nonsignificant correlation with mean monthly maximum temperature $(0.574)$, positive and significant correlation with mean monthly minimum temperature $(0.633)$ while, negative and non-significant correlation with mean monthly RH (-0.101). The mean abundance of A. flavus was positively and significantly correlated with mean monthly maximum (0.620) as well as minimum temperature (0.690) while, negatively and nonsignificantly correlated with mean monthly RH (-0.080). However, abundance of rot caused by $F$. pallidoroseum was negatively and significantly correlated with mean monthly maximum (-0.651) as well as minimum temperature (-0.725) and positively and non-significantly correlated with mean RH (0.160). Abundance of rot caused by Alternaria sp. was positively and nonsignificantly correlated with all three weather parameter under study $(0.249,0.390$ and 0.408 , respectively).

\section{Partial correlation between different post} harvest rots and weather parameters

A perusal of the data presented in Table 3 reveal that partial correlation between abundance of $C$. fructicola and weather factors was negative and significant (-0.811) with mean monthly maximum temperature, while, positive and significant (0.82) with mean monthly minimum temperature as well as with RH (0.718). Abundance of rot caused by $C$. truncatum was negatively and nonsignificantly correlated $(-0.130)$ with mean monthly maximum temperature while, positively and non-significantly correlated with mean monthly minimum temperature (0.072) as well as mean RH (0.122). However, partial correlation analysis between abundance of rot caused by $R$. stolonifer and weather factors depicted a non-significant correlation $(0.289,0.408$ and -0.259$)$ with all the three weather factors under study.

Abundance of rot caused by A. flavus and weather factors was also non significantly correlated with all the three factors being negatively correlated $(-0.340)$ with mean monthly maximum temperature while, positively correlated with mean monthly minimum temperature $(0.498)$ and mean $\mathrm{RH}$ (0.385). Abundance of rot caused by $F$. pallidoroseum was positively and non significantly correlated (0.372) with mean monthly maximum temperature, negatively and non significantly correlated with mean monthly minimum temperature $(-0.539)$ as well as mean RH (-0.299). 
Table.1 Prevalence of various post harvest rots of papaya in relation to weather parameters during 2019-20

\begin{tabular}{|c|c|c|c|c|c|c|c|c|c|}
\hline \multirow[t]{2}{*}{ Month } & \multirow{2}{*}{$\begin{array}{l}\text { Average } \\
\text { Maximum } \\
\text { temperature } \\
\left({ }^{\circ} \mathrm{C}\right)\end{array}$} & \multirow{2}{*}{$\begin{array}{l}\text { Average } \\
\text { Minimum } \\
\text { temperature } \\
\left({ }^{\circ} \mathrm{C}\right)\end{array}$} & \multirow{2}{*}{$\begin{array}{l}\text { Average } \\
\text { Relative } \\
\text { Humidity } \\
(\%)\end{array}$} & \multicolumn{6}{|c|}{ Average abundance of pathogen $(\%)$} \\
\hline & & & & $\begin{array}{c}C . \\
\text { fructicola }\end{array}$ & $\begin{array}{c}C . \\
\text { truncatum }\end{array}$ & $\begin{array}{c}R . \\
\text { stolonifer }\end{array}$ & A. flavus & $\begin{array}{c}F . \\
\text { pallidoroseum }\end{array}$ & $\begin{array}{c}\text { Alternaria } \\
\text { sp. }\end{array}$ \\
\hline May, 2019 & 41.26 & 28.97 & 18.29 & 11.00 & 0.00 & 0.00 & 10.50 & 76.50 & 0.00 \\
\hline June, 2019 & 43.97 & 31.20 & 21.36 & 0.00 & 0.00 & 85.50 & 54.10 & 0.00 & 0.00 \\
\hline July, 2019 & 37.87 & 28.03 & 55.29 & 86.11 & 0.00 & 77.79 & 100 & 17.20 & 4.72 \\
\hline August, 2019 & 35.13 & 26.74 & 68.60 & 78.70 & 0.00 & 72.43 & 40.74 & 40.33 & 12.06 \\
\hline $\begin{array}{l}\text { September, } \\
2019\end{array}$ & 33.90 & 25.27 & 71.83 & 70.79 & 83.31 & 0.00 & 23.05 & 50.89 & 2.50 \\
\hline October, 2019 & 31.87 & 21.16 & 53.17 & 57.26 & 74.78 & 0.00 & 22.33 & 53.47 & 0.00 \\
\hline November, 2019 & 28.27 & 17.90 & 44.08 & 56.36 & 74.17 & 0.00 & 19.11 & 66.33 & 0.00 \\
\hline December, 2019 & 20.77 & 11.71 & 50.75 & 51.01 & 66.10 & 0.00 & 0.00 & 70.62 & 0.00 \\
\hline January, 2020 & 18.19 & 9.09 & 69.77 & 16.72 & 0.00 & 0.00 & 0.00 & 83.47 & 0.00 \\
\hline February, 2020 & 23.21 & 10.97 & 62.07 & 15.88 & 0.00 & 0.00 & 0.00 & 84.85 & 0.00 \\
\hline March, 2020 & 27.13 & 15.19 & 58.40 & 15.09 & 0.00 & 0.00 & 0.00 & 86.44 & 0.00 \\
\hline April, 2020 & 36.33 & 22.57 & 28.59 & 14.87 & 0.00 & 0.00 & 13.67 & 79.97 & 0.00 \\
\hline
\end{tabular}


Table.2 Simple correlation between abundance of different post harvest rots in papaya and weather parameters

\begin{tabular}{|c|c|c|c|}
\hline \multirow{2}{*}{$\begin{array}{l}\text { Post harvest rot } \\
\text { caused by pathogen }\end{array}$} & \multicolumn{3}{|c|}{ Simple Correlation Coefficients } \\
\hline & $\begin{array}{l}\text { Disease abundance } \\
\text { with maximum } \\
\text { Temperature }\end{array}$ & $\begin{array}{l}\text { Disease abundance } \\
\text { with minimum } \\
\text { Temperature }\end{array}$ & $\begin{array}{c}\text { Disease abundance } \\
\text { with Relative } \\
\text { humidity }\end{array}$ \\
\hline C. fructicola & 0.022 & 0.201 & 0.526 \\
\hline C. truncatum & -3.555 & -0.340 & 0.250 \\
\hline R. stolonifer & 0.574 & $0.633 * *$ & -0.101 \\
\hline A. flavus & $0.620 * *$ & $0.690 * *$ & -0.080 \\
\hline F.pallidoroseum & $-0.651 * *$ & $-0.725 *$ & 0.160 \\
\hline Alternaria sp. & 0.249 & 0.390 & 0.408 \\
\hline
\end{tabular}

Table.3 Partial correlation between abundance of different post harvest rots in papaya and weather parameters

\begin{tabular}{|c|c|c|c|}
\hline \multirow{2}{*}{$\begin{array}{c}\text { Post harvest rot } \\
\text { caused by pathogen }\end{array}$} & \multicolumn{3}{|c|}{ Partial correlation coefficients } \\
\hline & $\begin{array}{l}\text { Disease abundance with } \\
\text { maximum Temperature. } \\
\text { r DITmax.RH\&Tmin. }\end{array}$ & $\begin{array}{l}\text { Disease abundance with } \\
\text { minimum Temperature. } \\
\text { r DITmin.RH\&Tmax. }\end{array}$ & $\begin{array}{l}\text { Disease abundance } \\
\text { with Relative } \\
\text { humidity } \\
\text { r DIRH. Tmax.\&Tmin. }\end{array}$ \\
\hline C. fructicola & $-0.811 *$ & $0.820 *$ & $0.718 *$ \\
\hline C. truncatum & -0.130 & 0.072 & 0.122 \\
\hline R. stolonifer & 0.289 & 0.408 & -0.259 \\
\hline A. flavus & -0.340 & 0.498 & 0.385 \\
\hline F. pallidoroseum & 0.372 & -0.539 & -0.299 \\
\hline Alternaria sp. & $-0.653 * *$ & $0.694 *$ & $0.729 *$ \\
\hline
\end{tabular}

$\mathrm{DI}=$ Disease incidence; $\mathrm{T}_{\max }=$ Maximum Temperature; $\mathrm{T}_{\min }=$ Minimum temperature; $\mathrm{RH}=$ Relative humidity

*Significant at $1 \%$ level of significance

** Significant at $5 \%$ level of significance 
Table.4 Regression equation revealing relationship between abundance of different post harvest rots in papaya and weather parameters

\begin{tabular}{|c|c|c|c|}
\hline $\begin{array}{l}\text { Post harvest rot } \\
\text { caused by } \\
\text { pathogen }\end{array}$ & Regression equation (s) & $\mathbf{R}^{2}$ & $\begin{array}{l}\text { Coefficient of } \\
\text { multiple } \\
\text { determination } \\
(\%)\end{array}$ \\
\hline C. fructicola & $\begin{array}{l}Y=94.83-10.43 X_{1}+12.10 X_{2}+0.44 X_{3} \\
(87.86) \\
(0.55)\end{array}$ & 0.695 & 69.50 \\
\hline C. truncatum & $\begin{aligned} Y= & 95.35-3.24 X_{1}+1.87 X_{2}+1.87 X_{3} \\
& (423.44) \quad(31.20) \quad(31.86)\end{aligned}$ & 0.130 & 13.00 \\
\hline R. stolonifer & $\begin{aligned} Y= & -54.62-1.43 X_{1}+4.86 X_{2}+0.37 X_{3} \\
& (138.471)(8.02) \quad(7.68)\end{aligned}$ & 0.454 & 45.40 \\
\hline A. flavus & $\begin{array}{l}Y=-47.02-1.35 X_{1}+4.51 X_{2}+0.39 X_{3} \\
\quad(103.242)(5.98)\end{array}$ & 0.557 & 55.70 \\
\hline $\begin{array}{l}\text { F. } \\
\text { pallidoroseum }\end{array}$ & $\begin{aligned} Y= & 80.51+3.71 X_{1}-6.56 X_{2}-0.05 X_{3} \\
& (94.05) \quad(5.45) \quad(5.22)\end{aligned}$ & 0.592 & 59.20 \\
\hline Alternaria sp. & $\begin{array}{l}Y=-6.01+0.44 X_{1}+0.77 X_{2}+0.11 X_{3} \\
(11.64) \quad(0.67)\end{array}$ & 0.623 & 62.30 \\
\hline
\end{tabular}

$\mathrm{X}_{1}=$ Maximum. Temperature; $\mathrm{X}_{2}=$ Minimum Temperature; $\mathrm{X}_{3}=\mathrm{RH} ; \mathrm{Y}=$ Pathogen

Figures in parentheses represent respective standard errors

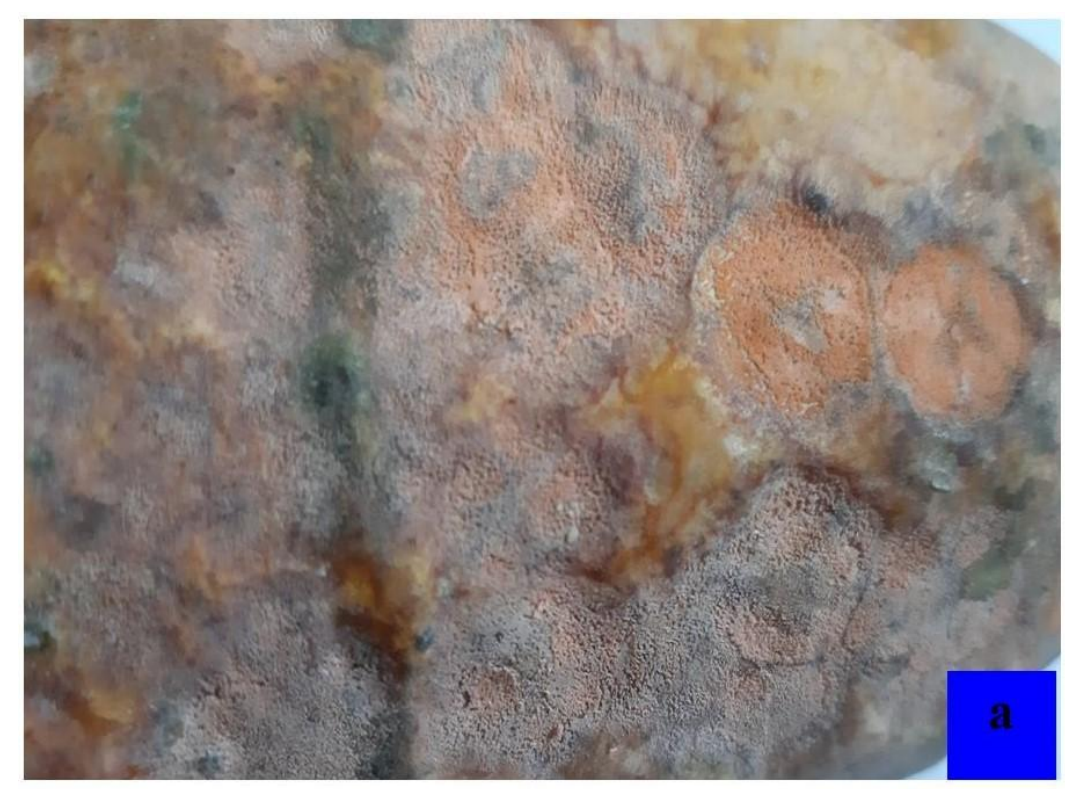

Figure1. Symptoms of C. fructicola 


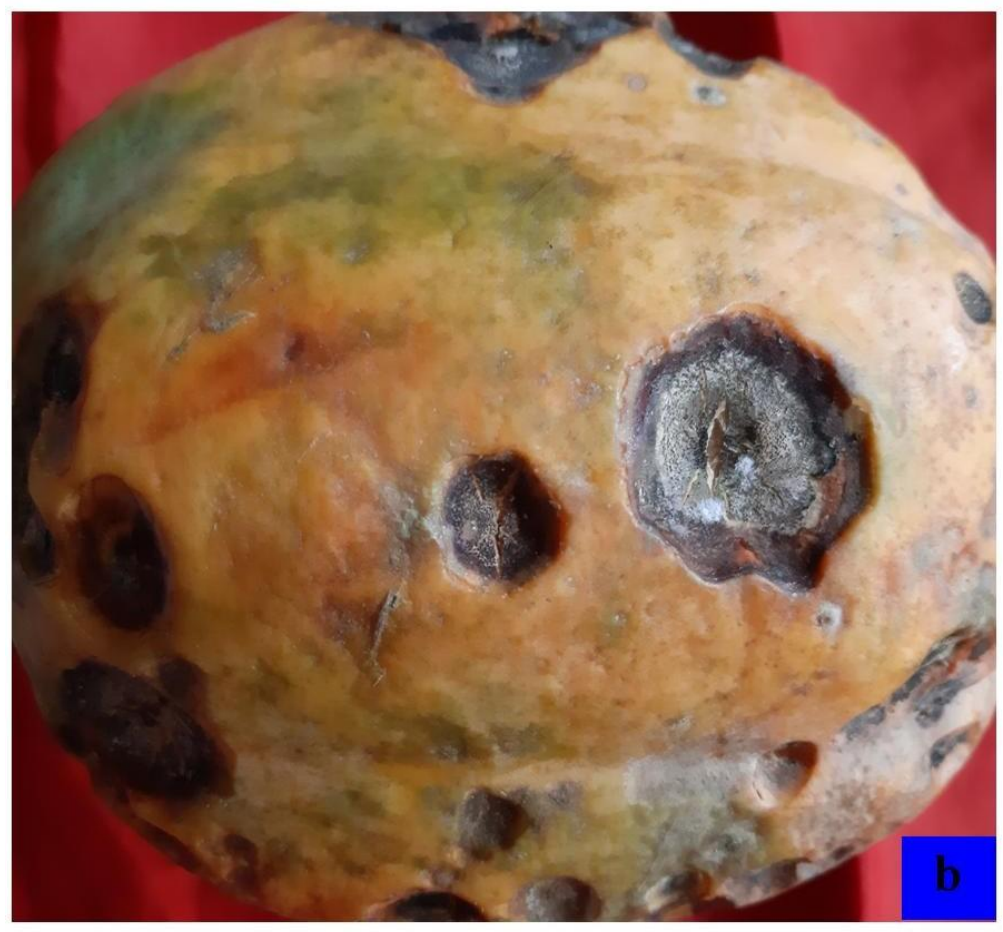

Figure 2. Symptoms of C. truncatum

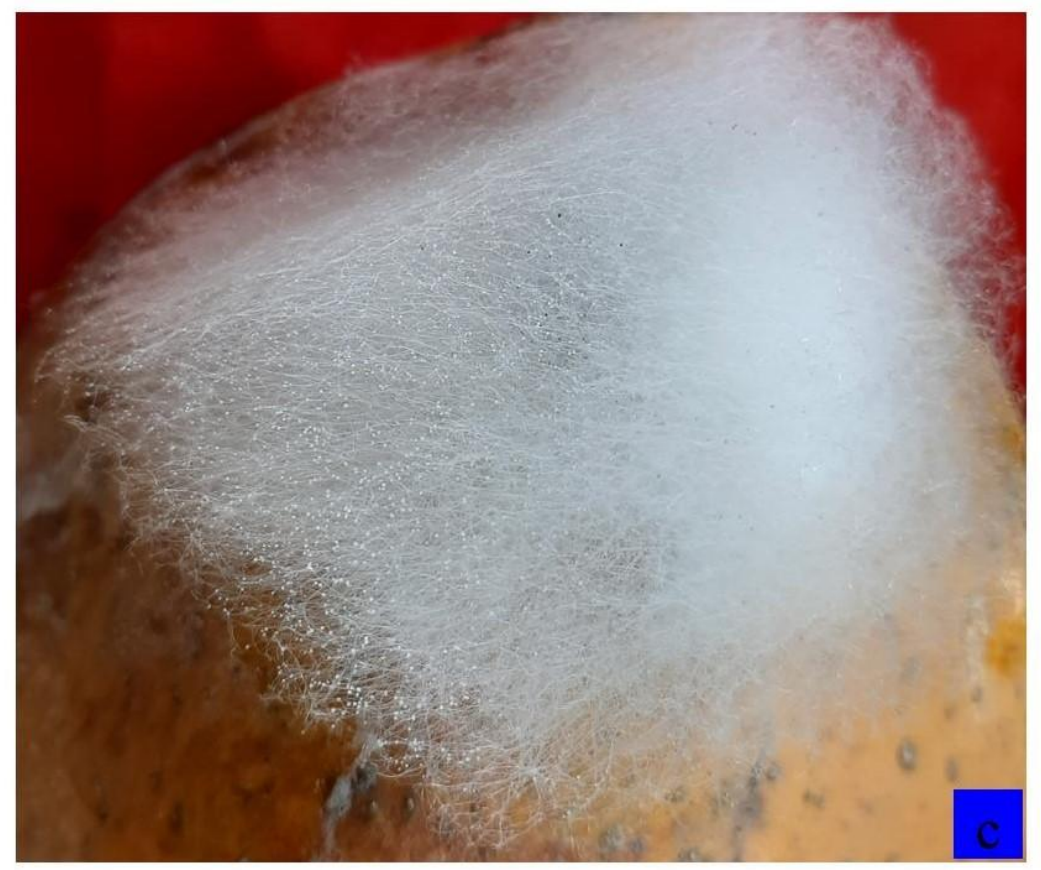

Figure 3. Symptoms of R. stolonifer 


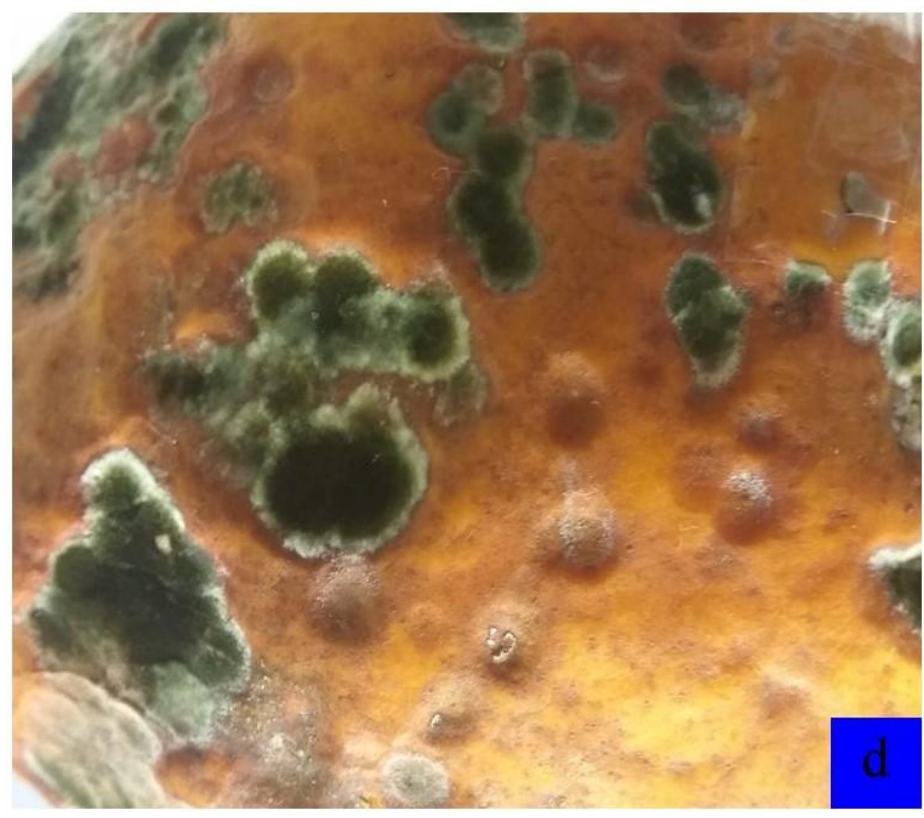

Figure 4. Symptoms of A. flavus

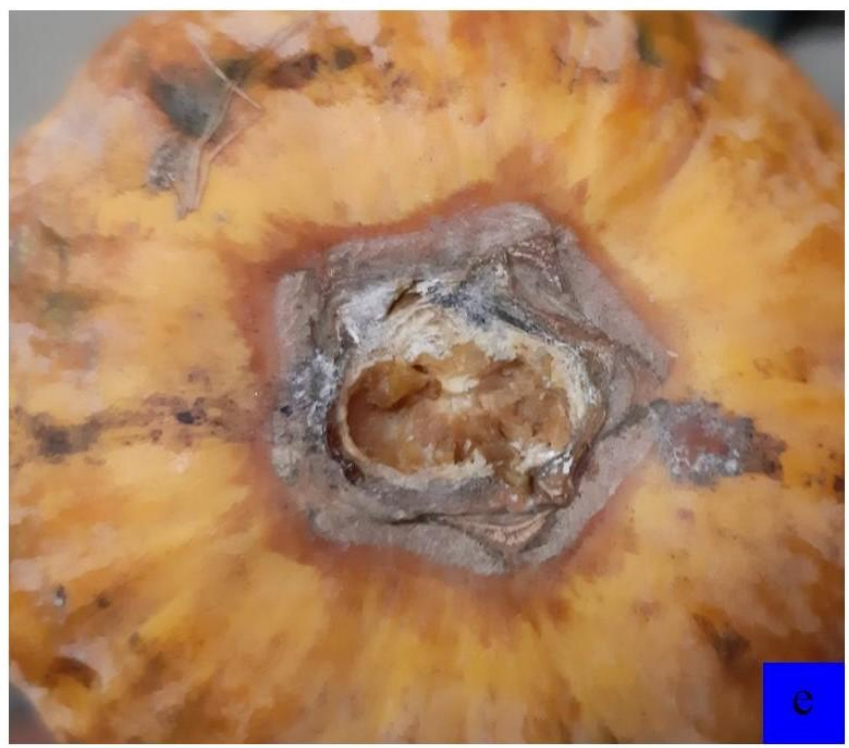

Figure 5. Symptoms of F. pallidoroseum 


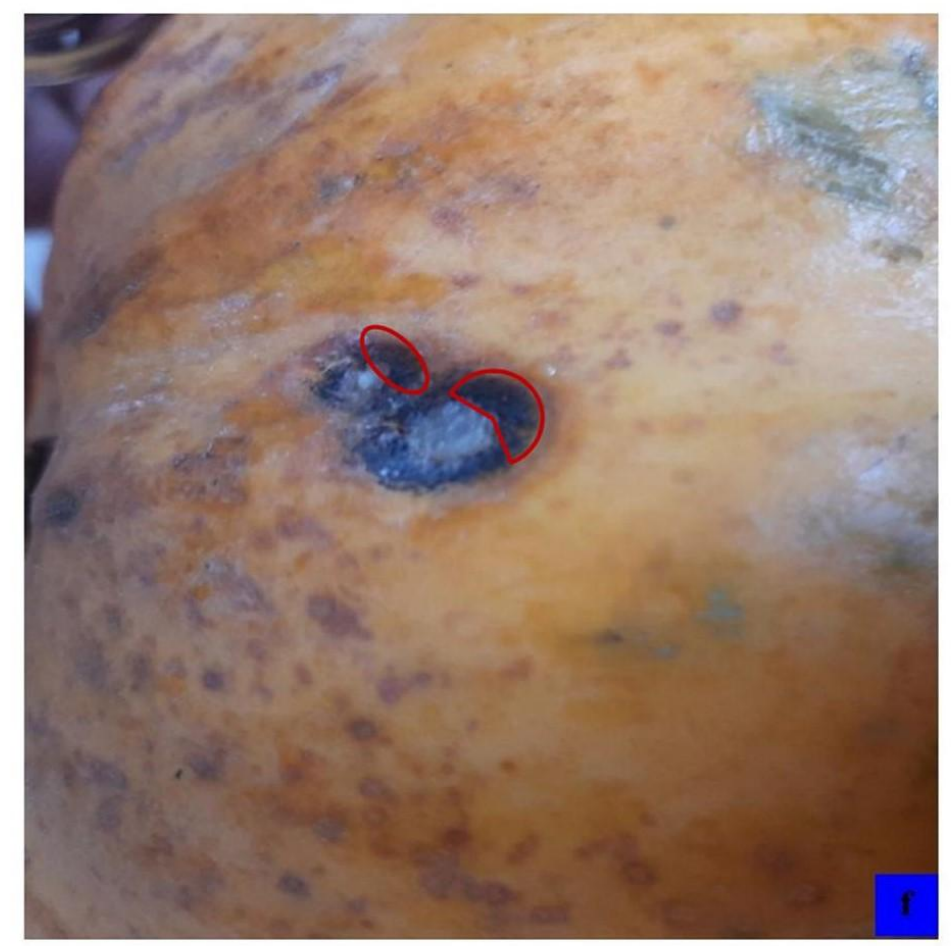

Figure 6. Symptoms of Alternaria sp.

Partial correlation analysis between abundance of rot caused by Alternaria sp. and weather factors indicated that mean pathogen abundance was negatively and significantly correlated (-0.653) with mean monthly maximum temperature while, positively and significantly correlated with mean monthly minimum temperature (0.694) as well as mean RH (0.729).

\section{Multiple regression between different post harvest rots and weather parameters}

Data presented in Table 4 reveal the multiple regression equation devised between different pathogens and group of independent variables which indicated that a unit change in mean maximum temperature, mean minimum temperature and mean $\mathrm{RH}$ could influence the disease abundance of rot caused by $C$. fructicola up to $-10.43,12.10$ and 0.44 units, respectively; $C$. truncatum up to $-3.24,1.87$ and 1.87 units, respectively; $R$. stolonifer up to $-1.43,4.86$ and 0.37 units, respectively; $A$. flavus up to $-1.35,4.51$ and 0.39 units, respectively; $F$. pallidoroseum up to 3.71 , 6.56 and -0.05 and Alternaria sp. up to 0.44 , 0.77 and 0.11 units, respectively.

The multiple coefficient of determination between disease abundance of rot caused by particular pathogen and group of independent variables were found to be $0.695,0.130$, $0.454,0.557,0.592$ and 0.623 for $C$. fructicola, $C$. truncatum, $R$. stolonifer, $A$. flavus, F. pallidoroseum and Alternaria sp., respectively thereby indicating that 69.50 , $13.00,45.40,55.70,59.20$ and 62.30 per cent change in the disease abundance of different rots caused by respective pathogens was attributed to all weather factors included in the studies collectively whereas, rest of the variation was due to unexplained factors not included in the investigations 
Five fungal species viz., Colletotrichum fructicola, C. truncatum, Rhizopus stolonifer, Aspergillus flavus, Fusarium pallidoroseum and Alternaria sp. were found to be associated with different post harvest rots in papaya during present studies. These findings are in conformity with various workers who have also reported the association of these pathogens with post harvest rots in papaya (Pooja et al., 2012; Aktaruzzaman et al., 2018 and dos Santos Vieria et al., 2019; Phoulivong et al., 2012 and Marquez-Zequera et al., 2018).

The symptoms of various rots observed are the same as described by Sharma and Kulshrestha (2015), Aktaruzzaman et al., (2018), Popat (2013), Pooja et al., (2012), Singh et al., (2012) and Patel (2013).

Abundance of various rots varied in different months under study according to varying temperature and $\mathrm{RH}$ conditions. Earlier, Baiyewu and Amusa (2005) and Gore et al., (2016) have reported that fungal rot caused by Colletotrichum sp. could develop well at temperature range 27 to $35^{\circ} \mathrm{C}$ with relative humidity between 60-80 per cent. Sommer (1982) reported $R$. stolonifer to grow on tomato fruits at $27^{\circ} \mathrm{C}$ and high relative humidity. Therefore, the disease usually increased during rainy season. However, as per Schipper (1984) and Liou et al., (2007), $24^{\circ} \mathrm{C}$ is optimum temperature for the growth of $R$. stolonifer and it can grow on strawberry fruits at a temperature range of 8 to $33^{\circ} \mathrm{C}$. But, the fungus has been reported to thrive well even up to $60^{\circ} \mathrm{C}$ which is the thermal death point of this fungus (Langeron and Vanbresueghem, 1965). Holmquist et al., (1983) recorded best growth of A. flavus at $33^{\circ} \mathrm{C}$. However, Belli et al., (2004) reported 30 and $37^{\circ} \mathrm{C}$ to be optimum temperature for the growth of Aspergillus sp. on grapes. Mitchell (2004) reported $30-35^{\circ} \mathrm{C}$ to be the optimum temperature for most of the Aspergilllus sp. strains on grapes. Gore et al.,
(2016) has also reported that Fusarium sp. could grow at temperature range $20-35^{\circ} \mathrm{C}$ with an optimum at $27^{\circ} \mathrm{C}$. Also, our findings are supported by Nagaraja et al., (2011) who reported a temperature range 25 to $27^{\circ} \mathrm{C}$ to be optimum for growth of Fusarium sp. Our findings pertaining to Alternaria rot are in conformity with Smilanick and Mansour (2007) and Hudge and Datar (2009) who reported that $A$. alternata could grow well at a temperature range $20-35^{\circ} \mathrm{C}$ with sporulation at 25 to $27^{\circ} \mathrm{C}$.

Correlation and regression analyses between any post harvest rot of papaya and weather parameters have never been conducted by any researcher, so these results cannot be compared with available literature. However, it is a well known fact that temperature and relative humidity are two major factors influencing the outbreak of any disease (Agrios, 2005). Whereas, other than these two factors, many other factors are also responsible for the disease development. From the coefficients of multiple determinations between different rots and weather parameters under study, it was concluded that these factors could influence the outbreak of different rots only below 70 per cent. This can be attributed to the fact that the post harvest rots generally develop during transportation and storage and actual temperature and relative humidity prevailing under these conditions might be somewhat different from outside weather conditions.

From this study it was concluded that different post harvest rots of papaya were prevalent throughout the year and were influenced by weather parameters like temperature and relative humidity. These results do give us an idea about the role of these three factors under investigation in the development of different post harvest rots and open avenues for further studies on this aspect. 


\section{References}

Agrios, G.N. (2005). 5th ed. Plant Pathology. Academic Press, New York, 952p.

Aktaruzamann, M., Afroz, T., Li, Y.G., and Kim, B.S. (2018). Post harvest anthracnose of papaya caused by Colletotrichum truncatum in Korea. Eur. J. Plant Pathol. 150(1), 259-265.

Alvarez, A.M., and Nishijima, W.T. (1987). Postharvest diseases of papaya. Plant Dis. 71(8), 681-686.

Baiyewu, R.A., and Amusa N.A. (2005). The effect of temperature and relative humidity on paw-paw fruit rots in South-Western Nigeria. World J. Agri. Sci. 1(1), 80-83.

Belli, N., Marin, S., Sanchis, V., and Ramos, A.J. (2004). Influence of water activity and temperature on growth of isolates of Aspergillus section nigri obtained from grapes. Int. J. Food Microbiol. 96(1), 19-27.

dos Santos Vieria, W.A., Santos Nunes, A., Veloso, J.S., Machado, A.R., Balbino, V.Q., da Silva, A.C., Gomes, A.A.M, Doyle, V.P., and Camara, M.P.S. (2019). Colletotrichum truncatum causing anthracnose on papaya fruit (Carica papaya) in Brazil. Australas. Plant Dis. 15(2).

Gore, N., Kumthekar, R., Chaure, A., and Harke, S. (2016). Probiotic Lactobacillus as bio-control agent of post harvest diseases of banana and papaya fruits. Int. J. Curr. Res. 8(5), 31388-31392.

Holmquist, G.U., Walker, H.W., and Stahr, H.M. (1983). Influence of temperature, $\mathrm{pH}$, water activity and antifungal agents on the growth of Aspergillus flavus and A. parasiticus. J. Food Sci. 48(3), 778782.

Hudge, B.V., and Datar, V.V. (2009). In vitro effect of temperature and humidity against Alternaria alternata (Fr.)
Keissler causing leaf spot of Jatropha. J. Annu. Plant Physiol. 23, 129-130.

Langeron, M., and Vanbresueghem, R. (1965). $2^{\text {nd }}$ edition. Outline of Mycology Langeron. Pitman Publishing, $426 \mathrm{p}$.

Liou, G.Y., Chen, S.R., Wei, Y.H., Lee, L.F., Fu, H.M., Yuan, G.F., and Stalpers, G.A. (2007). Polyphasic approach to the taxonomy of the Rhizopus stolonifer group. Mycol. Res. 111(2), 196-203.

Lustria, J.U.J., Nacional, A., and Morillo, A.E. (2009). Commodity situation report: Papaya. Working paper. $34 \mathrm{p}$

Marquez-Zequera, I., Cruz-Lachica, I., LeyLopez, N., Carrillo-Facio, J.A., OsunaGarcia, L.A., and Garcia-Estrada, R.S. (2018). First report of Carica papaya fruit anthracnose caused by Colletotrichum fructicola in Mexico. Plant Dis. 102(12), 2649.

Mitchell, D., Parra, L., Aldred, D., and Magan, N. (2004). Water and temperature relations of growth and ochratoxin A production by Aspergillus carbonarius strains from grapes in Europe and Israel. J. Appl. Microbiol. 97(2), 439-445.

Nagaraja, A., Usha, K., Singh, B., Singh, S.K., and Umamaheswari, C. (2011). Effect of temperature and relative humidity on growth and sporulation of Fusarium mangiferae under in vitro conditions. Indian J. Hortic. 68(1), 3638.

Patel, J.B. (2013). Mycoflora involved in post harvest fruit rot of papaya (Carica papaya L.) and its management. $\mathrm{PhD}$ Thesis.Navsari Agriculture University, Navsari, $161 \mathrm{p}$.

Phoulivong, S., McKenzie, E.H.C., and Hyde, K.D. (2012). Cross infection of Colletotrichum species; a case study with tropical fruits. Curr. Res. in Environ. Appl. Mycol. 2(2), 99-111. 
Pooja, S., Mishra, A.K., and Tripathi, N.N. (2012). Assesment of mycoflora associated with post harvest losses of papaya fruits. J. Agric. Technol. 8(3), 961-968.

Popat, S.R. (2013). Studies on efficacy of garlic extract and yeast for the control of post harvest diseases of major fruit crops. MSc. Thesis. Mahatma Phule Krishi Vidyapeeth, Rahuri, 81 p.

Sankat, G.K., and Maharaj, R. (1997). Papaya. In: Post Harvest Physiology and Storage of Tropical and Sub Tropical Fruits by S K Mitra (ed.), CAB International, UK, pp. 167-189.

Schipper, M.M.A. (1984). Revision of the genus Rhizopus. Studies in Mycology. 25:1.

Sharma, M. and Kulshrestha, S. (2015). Colletotrichum gloeosporioides: An anthracnose causing pathogen of fruits and vegetables. Biosci. Biotech. Res. Asia. 12(2), 1233-1246.
Singh, I. (1990). Papaya. Oxford and IBH Publishing Co. Pvt Ltd, New Delhi, 224 p.

Singh, P., Mishra, A.K., and Tripathi, N.N. (2012). Assessment of mycoflora associated with post-harvest losses of papaya fruits. J. Agric. Sci. Technol. 8(3), 961-968.

Smilanick, J.L., and Mansour, M.F. (2007). Influence of temperature and humidity on survival of Penicillium digitatum and Geotrichum citri-aurantii. Plant Dis. 91:990- 996.

Sommer, N.F. (1982). Postharvest handling practices and postharvest diseases of fruit. Plant Dis. 66:357-364.

Zhu, X., Li, X., Chen, W., Lu, W., Mao, J. and Liu, T. (2013). Molecular cloning, characterization and expression analysis of cpcbf 2 gene in harvested papaya fruit under temperature stresses. Electron $\mathrm{J}$ Biotechn. 16(4), 1-10.

\section{How to cite this article:}

Priyanka Bhardwaj, Kumud Jarial, R. S. Jarial and Dinesh Kumar. 2020. Effect of Weather Parameters on the Development of Post Harvest Rots of Papaya. Int.J.Curr.Microbiol.App.Sci. 9(10): 855-867. doi: https://doi.org/10.20546/ijcmas.2020.910.102 